\title{
IGALA PROVERBS AS CORRECTIONAL TOOLS IN THE HANDS OF TRADITIONAL ELDERS
}

\author{
Sunday Emah Sule*, Sunday Joseph Ojonugwa* \\ \& \\ Joseph Akanya* \\ http://dx.doi.org/10.4314/og.v15i1.12s
}

\begin{abstract}
Igala proverbs play a very important role in everyday language of the Igala people. The language has beautiful proverbs which cover all aspects of the people's life and culture. These proverbs are drawn from careful observation of social events, the lives of people and animals. Also, some proverbs have traces of experiences of the people's occupations such as farming, fishing, hunting, weaving, wrestling and dancing. The language has proverbs that talk above family and human relations, good and evil, poverty and riches, joy and sorrow. It is on this basis that this study examines how the elders/traditional leaders who are custodians of Igala cultural values use proverbs as a generalized code for establishing standards in ethical and moral values, enthroning respect for elders and constituted authorities and discouraging the youths from embracing social vices prevalent in our society. This study adopts Dan Sperber's and Wilson's (1986) relevance theory. Participant observation and interview were the means of data collection. The data collected were analyzed using descriptive and analytical tools. The work uses the traditional contexts of Ogugu and Ankpa proverbs to present their epistemological significance in Igala kingdom.
\end{abstract}

Keywords: Igala Proverbs, Correctional Tools, Traditional Elders, Relevance Theory, Traditional Institutions.

\section{Introduction}

There seems to be a gradual introduction and implementation of Western philosophies and symbols in Igala tradition that is overshadowing and collapsing the conventional methods being cherished before. These philosophies are increasingly making their way into the traditional cottage of the Igala people as they are being 
Sule, Ojonugwa \& Akanya: Igala Proverbs as Correctional ...

presented and painted as a new way of life superior to the existing traditional practices. The introduction and gradual implementation of the Western philosophies and symbols according to Asare poses great threats to Igala cultural values as most of the youths turn to neglect the Igala rich cultural values totally (14).

In Igala Traditional ambience, there exists a long standing system that addresses all aspects of Igala people including the system of bringing up the younger ones. Comparatively, the Western education is therefore merely schooling and it remains only an insignificant aspect of the education in relation to the Igala indigenous concept of education. In the traditional mode, the moral physical, social, spiritual and economic considerations in relation to the needs of the society are very central (Egbunu, 19). In the Igala traditional worldview, what constitutes best education are characteristically measured on the basis of the development of the intellectual skills. As a matter of fact, in Igala traditional system according to Egbunu (48), every meaningful member of the society (especially every elder) was a teacher, because it is believed, "alu ogijo m'agbulu omiẹka" (the elders are custodians of wisdom). Every genuine elder is indeed considered a mini-encyclopedia of traditional wisdom, using the tradition to carefully transmit the original version of every cultural value through proverbs to the younger ones.

Igala proverbs are enigmatic traditional concept which belongs to culture and used to foreground the values and shared beliefs held by every members of the society which the young ones meet and practice as they grow up, as most of the lessons are either passed on orally or through careful observation and practice as children learn the trade of their parents or elders within their environs. Farming, fishing, hunting, smiting, building, setting of broken bones, folksongs, brewing of local liquor, weaving, dyeing or farming may be undertaken by the women folk. It is a tradition among the Igala that "Ud'ama ch'ukpahiu" (unity is power). Togetherness is seen as a great source of strength or power. As it is often expressed in proverbs, "alu ma mujọn ya fufun" (if the lips do not come together there can never be successful whistling); "oli katete adago amud'okon" (a tree cannot make a forest); "omọwọ katete any'oji adinan" (no single finger can bring lice from the hair) (Egbunu, 21). 
Whether or not some of the assertions or allusions made in the proverbs rendered lack plausibility in certain situations is not our point of concern here. It is only necessary to note at this point that these ideas form a good part of what the Igala person cherishes.

\section{Theoretical Basis}

The work is hinged on the relevance theory of (1986) by Dan Sperber and Deirdre Wilson. The theory draws basically from one of Grice's Maxims (Maxim of relation: Make your contribution relevant) in his theory of conversation. The theory of relevance is a general attempt to ground models of human communication in cognitive psychology. The theorists strongly believed that communication is successful not when hearers recognize the linguistic meaning of an utterance but when they infer speaker's meaning from it. This position opposed the earlier theories of communication which are based on the code model (that communication is achieved by decoding and encoding message). The theory represents a framework for linking the major dimensions of social interaction with the ways in which people talk with one another. This approach postulates some basic notions that are of utmost importance in human communication.

\section{Explicit and Implicit Communication Model}

When an utterance is made, it represents the speaker's intention and meaning which in case of assertion, is a set of assumptions where one of the assumptions is explicitly expressed and the other implicitly conveyed. The theory asserts that the essential feature of most human communication, both verbal and non-verbal, is the expression and the recognition of intentions.

\section{Cognitive Environment}

This basic notion of the theory has to do with the set of facts that are manifest to an individual. The total cognitive environment of an individual is a practical function of his physical environment and cognitive abilities. 
Sule, Ojonugwa \& Akanya: Igala Proverbs as Correctional ...

\section{Manifest}

When an individual is capable of constructing as true or probably true of any assumption, manifest is practised. To be manifest, therefore is to be perceptible.

The theory is considered appropriate for this research because it explains the relationship between the SPEAKER $\longrightarrow$ Memory $\longrightarrow$ HEARER, with the aim to explain in cognitively realistic terms what expectations of relevance amount to and how they might contribute to an empirically plausible account of comprehensions.

Igala proverbs on the other hand are context oriented, pedagogical and anthropological that arguably need a speaker processing memory and the hearer before the whole complex of knowledge inherent in the proverbs can be acquired. The acquisition comprises many aspects, namely, language, knowledge, human institutions, technology, beliefs, tradition and customs.

\section{Creation of Igala Proverbs}

In the case of Igala traditional proverbs, no trace has generally been left on the historical landscape to indicate when they were created originally or by whom. In an interview with Baba Iyodo of Ochaja (personal communication 2018), it became clear that legends do not name the creators of proverbs although proverbs are frequently included in the utterances of these legends. To the legends and the elders, proverbs are involuntary actions as they unconsciously and consciously use to embellish their statements over the discussion on ground. Proverbs come about for several reasons, and in many ways. Some may arise from simple apophthegms and platitudes which over time are elevated to the status of a proverb. Others emerge from the symbolic or metaphoric use of an incident; some are based on a story or fable, while others are simply variations on existing proverbs. In non-literate communities, it is virtually impossible to even approximately date proverbs (Egbunu, 4).

The origin of any proverb has usually been a concise, brief or figurative statement usually from speeches of a wise or elderly man, in a particular situation or context. If it expresses his audience as rich as weighty with cherished wisdom, anybody may quote it in a similar situation and as time goes on, it becomes a popular expression in the language of the people. Proverbs with moral 
Ogirisi: a new journal of African studies vol. 15s 2019

significance become fashionable and popular and are adopted into the social ethics of the people (Ackah, 98).

About how proverbs are formed, Halm in Peace (13) states that proverbs are rooted in folklore and have been preserved by oral tradition. An example of such common place wisdom is 'A rolling stone gathers no moss'. Some Igala proverbs have literary origins. According to Benjamin's adoption of Aesop's proverb, 'the gods help them that help themselves'. Proverbs are generally appealing because they are brief and they use simple rhyme, proverbs can be formulated by anybody by the choice of his words of interest that contains wisdom and carry information to warn, advice and appraise a situation, or a person.

\section{Igala Proverbs}

Ita in Igala literally means proverbs, phrase or group of words with peculiar or special meanings different from the usual meaning of each of the words used in the expression. Igala proverbs, like any other proverbs globally are accumulated wisdom of the ancients that are usually dished out beautifully during conversations, to beautifully support an argument or emphasize a particular point in the course of speech making or bookwork. Linguistically, there are series of proverbs for every facet of human endeavour in Igala culture (Adebo, 24). In Igala language, the essence of the proverbs is to guide man and educate him morally and philosophically not the non-living things and animals; that is the main reason why proverbs are usually translated wholly with fixed meanings. Usually a verb or word for its contextual meaning, consequently giving lexical or distinctive meaning to a proverb. This is because proverbs are imaginative expressions such as idioms and wise sayings that are considered as Ita (proverb) with their unique definitions. On the other side, literal translation usually negates its linguistic excellence and philosophical relevance. Some of the examples are; Abioma $a^{\prime} k w u$ - literally, it means mothers cannot escape death, but the real meaning is mothers too are humans that need food for their own survival. This proverb evolved out of a situation where a child was always crying for food to the detriment of the mother, and the child was told that his mother was a human being who equally needed food for her survival. Also, Achichi anya'ja aren meaning, flies don't trade in glue, but the actual meaning is human beings should 
Sule, Ojonugwa \& Akanya: Igala Proverbs as Correctional ...

not by any reason commit suicide or engage in activities that can lead to their death. Similarly, Adu a'dọla - $\tilde{n} w u$ adu this literally means, a slave calls himself a slave, but is really difficult for a slave to call himself a slave. This classical proverb has to do with one's behaviour or character, that is why it is usually translated as, judge people by the way they behave, not by their appearance. In Igala language, some proverbs have more than one meaning while a couple of other proverbs have similar meanings, though, in most cases, each of them has a shade of meaning peculiar or unique to itself. Igala proverbs are classified under the followings:

i. Proverbs that mention God, the gods, mother earth, rivers, and other spirits of the universe.

ii. Proverbs that relate with animals and men.

iii. Proverbs that deal with historical explanations or stories.

iv. Proverbs in which parts of the body such as ears, hands, eyes, and brain are mentioned.

v. Proverbs that refers to natural vegetations and plantation.

vi. Proverbs which refer to the general state of man, his fate, and his destiny.

vii. Proverbs that address the domestic, social and political life of the people.

viii. Proverbs that talk about human relations.

ix. Proverbs that talk about superstitious and general beliefs.

x. Proverbs which refer to the intellectual conditions of man e.g. wisdom, foolishness, rudeness, relationships, adventures and partnerships.

xi. Proverbs that refer to the moral values e.g. patriotism, love, unity, fairness, hard work, patience, justice, truthfulness, loyalty and contentment.

\section{Use of Proverbs in Igala Traditional Communities as Correctional Tools}

Moon (11) says that traditional proverbs clearly served a didactic purpose, despite the absence of western - styled institutions of learning. The correctional value of proverbs has a broad basis. Igala proverbs "awaken and enlarge reflections on the world and the nature of man, to suggest subjects for conversations or to provide themselves with appropriate to situations in everyday activity of 
man. Such purposes are obviously closely allied to the essence of the moralizing proverb". The preservation of proverbs in their original form would have certainly been guaranteed in traditional Igala communities by the means of correcting the societal ills prevalent in this generation. Igala proverbs according to Achor, has been and remains a most powerful correctional tools and effective instrument for the transmission of culture, social morality, manners and ideas of a people from one generation to another. The reason the efficacy of the proverb is that it is aphorism, a wise saying based upon people's experience, and is a reflection of the social values and sensibility of the people (27). The Igala proverb is a collection of a real sense of an ethnography of the Igala people, which if systematized can give a penetrating picture of the people's way of life, their philosophy, their teaching, their beliefs, their criticism of life, moral truths and social values (Ajimoko, 81).

Similarly, at the individual level, Igala proverbs fit into the syntax of speech as a figurative expression, and a stylistic device with the desired semantic force. Collectively and in an important general sense, Igala proverbs are literary forms which offer the traditional artist, speaker, philosopher and priest a veritable tool for the correction and moderation of an individual life for a better tomorrow. According to Chuta (4), whenever there is doubt about an accepted pattern of behaviour, whenever there is doubt about a stipulated line of action or a pattern of address, whenever traditional norms and principles are threatened, there are always proverbs to vouch, illuminate and buttress the wisdom of the traditional code of conduct. Edimeh confirms this when he said that Igala proverbs are graphic expressions that express a truth of experience. Its beauty and source of delight is that what it says is readily perceived and accepted as an incontrovertible truth. The truth presented in the proverb is not a logical, a priori or intuitive truth; it is often an empirical fact based upon and derived from the people's experience of life, human relationship and interaction with the world of nature (18).

Igala proverbs, as short popular saying in the form of expression of truth and offer of advice based on the experiences of the past, or an observation in a strikingly figuration language. It is marked by its epigrammatic terseness and by the readily acceptance of its truth to correct, shape, moderate the lives of the youths and 
Sule, Ojonugwa \& Akanya: Igala Proverbs as Correctional ...

provoke them through the use of skillful proverbs to run away from actions capable of destroying their bright destinies and a brace the values, truths and morals that society upholds.

\section{Significance of Proverbs in Igala Language}

From the preceding discussion, it is obvious that proverbs play very significant role in the everyday language of the Igala people. It is clear that beautiful proverbs abound in the language of the Igala people, particularly the Ogugu and Ankpa districts of the Igala kingdom. Igala proverbs are also known as marks of identity, social recognition and symbols of authority in the hands of the traditional elders. When Igala person uses a proverb and uses it well for effective buttressing of point, we say he really knows the language. Instead of long speech, a good speaker sometimes uses proverbs to express the same idea. According to Bokor (4), some of the functions of proverbs are as follows:

1. Proverbs adorn the speech and make it rich and beautiful.

2. They bring out the main point of the matter for clear understanding.

3. They make an otherwise long statement short.

4. Proverbs make listeners pay attention to what is being discussed.

5. Proverbs shape, correct, position the young for a better tomorrow.

6. They educate and teach morals.

These are different proverbs for different situations. For instance, a proverb that will be used when a lazy child is being advised will be totally different from when a hardworking child is being praised. Sometimes, two or more proverbs may convey almost the same meaning. So although there are different proverbs for different situations, most of the Igala proverbs are expressed to correct ugly situation and replace it with generally acceptable norms and social beliefs. It is clear from here that each proverb has a moral idea to pass to the listeners through teaching. When a proverb is given, the listeners try to find out what exactly is expressed and what intension is the speaker passing across and what lesson it is meant to teach. 


\section{Methodology}

Participant observation and interviews were the major data gathering technique in this research. The three researchers are indigenes of Kogi East senatorial district; a senatorial district dominated by Igala people. They are very much conversant with some of the proverbs in the language and know the situation of use of some of the Igala proverbs. They have equally served as cupbearers to some of the traditional elders and leaders from Ogugu and Ankpa Igala extraction. The two communities (Ogugu and Ankpa) cherish the use of proverbs as correctional tools particularly if it has to do with the growing generation. The researchers have thus selected some samples of data that best illustrate proverbs as correctional tools in the hands of our traditional elders. Our focus is on how the rich Igala proverbs can be harnessed and used as a generalized code to correct the ills of the society and enthrone the much desired peace and tranquility in our society.

\section{Data Presentation and Analysis}

The appealing aspect of Igala proverbs is that they are down-to-earth and practical. However, that does not mean that they are very easy to interpret. In fact, because proverb is so true - to - life, it is possible to find contradictions. A tabular procedural format of data presentation was adopted for this study. First is the presentation of Igala proverbs and the (English version - EV) communicative value/situation of use and the moral lesson

Table 1: Samples of Proverbs Illustrating Warning and Caution from the Elders toward the Youths

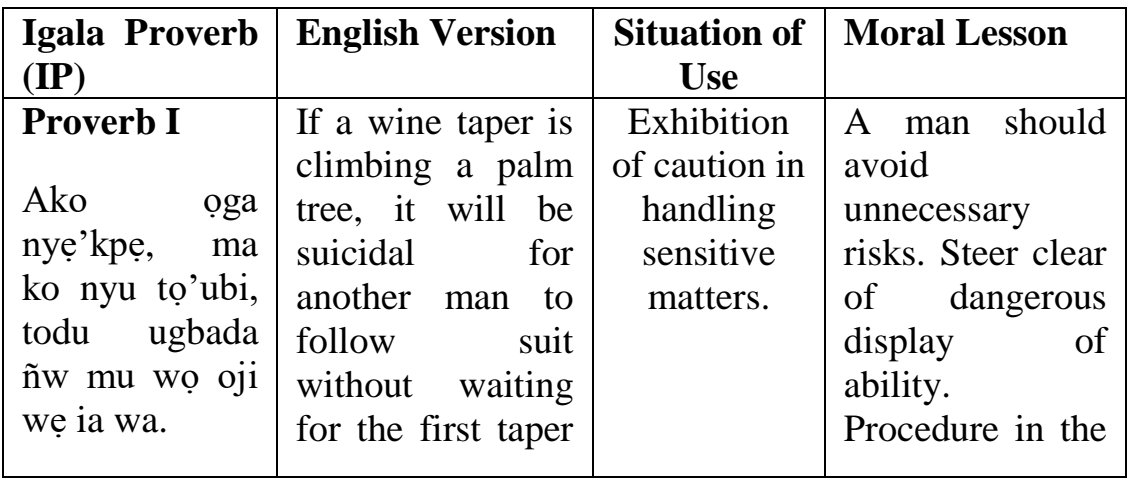


Sule, Ojonugwa \& Akanya: Igala Proverbs as Correctional ...

\begin{tabular}{|c|c|c|c|}
\hline & $\begin{array}{l}\text { to climb down; a } \\
\text { serious accident } \\
\text { is likely. }\end{array}$ & & $\begin{array}{l}\text { accomplishment } \\
\text { of a particular } \\
\text { task must be } \\
\text { adhered to, else } \\
\text { any attempt at } \\
\text { the short cut } \\
\text { may attract } \\
\text { severe } \\
\text { consequences. }\end{array}$ \\
\hline $\begin{array}{l}\text { Proverb II } \\
\text { Akoto ma } \\
\text { d'ẹñu ada' n, } \\
\text { ada aneke kpan } \\
\text { a' titin. }\end{array}$ & $\begin{array}{l}\text { If a giant roden } \\
\text { does not attempt } \\
\text { to take an object } \\
\text { from a set rap, it } \\
\text { cannot be caught } \\
\text { in the process, } \\
\text { especially where } \\
\text { there is nobody } \\
\text { contact. }\end{array}$ & $\begin{array}{l}\text { To caution } \\
\text { or warn a } \\
\text { child over a } \\
\text { particular } \\
\text { act or } \\
\text { person. }\end{array}$ & $\begin{array}{l}\text { Keep a thousand } \\
\text { mile distance } \\
\text { from bad people } \\
\text { or trouble - } \\
\text { When a man } \\
\text { keeps a safe } \\
\text { distance, he will } \\
\text { not fall into } \\
\text { trouble. }\end{array}$ \\
\hline $\begin{array}{l}\text { Proverb III } \\
\text { Ẹnẹ k'ima nyu } \\
\text { gbo oroọn, ọr'ọ } \\
\text { ato ọla ñw. }\end{array}$ & $\begin{array}{l}\text { If you do not go } \\
\text { close to okro } \\
\text { soup, it will not } \\
\text { have any contact } \\
\text { with you. }\end{array}$ & $\begin{array}{l}\text { To always } \\
\text { stay out of } \\
\text { trouble. }\end{array}$ & $\begin{array}{l}\text { Reckless } \\
\text { lifestyle and lack } \\
\text { of careful } \\
\text { watchfulness can } \\
\text { lead to careless } \\
\text { death. }\end{array}$ \\
\hline
\end{tabular}

From the above data, it is obvious that the use of proverbs in Igala traditional setting is indispensable as Igala traditional values are principally expressed and transmitted by means of oral traditions such as proverbs and others. The data above show the speakers' attitude towards the listener in relation to the proposition in the proverb being expressed as he wants the listener to be careful in whatever he engages himself. The proverbs above harp on caution, carelessness, portends negative consequences for the perpetrators with generational impacts. The underlying significance of the proverbs used above in the hands of the Igala traditional elders in 
Ogirisi: a new journal of African studies vol. 15s 2019

correcting the younger generation is enormous. The proverbs stand to correct so many things in the lives of the youths such as anger, greed, inordinate ambition, foolish associations and so on. The proverbs emphasized the benefit of peaceful resolution and show the need to desist from all forms of evil as they portend far reaching negative consequences.

Table 2: Samples of Proverbs Showing Truth and Sincerity among the Young People

\begin{tabular}{|c|c|c|c|}
\hline $\begin{array}{l}\text { Igala Proverb } \\
\text { (IP) }\end{array}$ & $\begin{array}{l}\text { English } \\
\text { Version } \\
\end{array}$ & $\begin{array}{l}\text { Situation of } \\
\text { Use }\end{array}$ & Moral Lesson \\
\hline $\begin{array}{l}\text { Ara'kwu aago } \\
\text { anẹ }\end{array}$ & $\begin{array}{l}\text { One who cries } \\
\text { can also see }\end{array}$ & $\begin{array}{l}\text { It is used to } \\
\text { express factual } \\
\text { truth to any } \\
\text { one even when } \\
\text { one is in pain. }\end{array}$ & 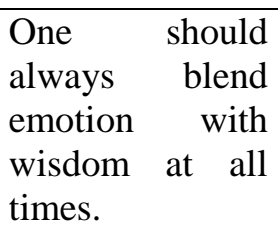 \\
\hline $\begin{array}{lr}\text { Olubọ } & \text { imọtọ } \\
\text { muda, } & \text { ogijo } \\
\text { ag'wu } & \text { gwu } \\
\text { efunwu } & \end{array}$ & $\begin{array}{l}\text { When good } \\
\text { fortune smiles } \\
\text { on a child even } \\
\text { the elderly will } \\
\text { want to benefit } \\
\text { from it. }\end{array}$ & $\begin{array}{l}\text { It is used to as } \\
\text { a piece of } \\
\text { advice to } \\
\text { children to be } \\
\text { progressive } \\
\text { rather than } \\
\text { take to } \\
\text { jealousy. }\end{array}$ & $\begin{array}{l}\text { Igala culture } \\
\text { forbids jealousy } \\
\text { and envy. }\end{array}$ \\
\hline $\begin{array}{l}\text { Imọtọ ki tọfa } \\
\text { ñw gunu owñu } \\
\text { d'ọla ñw ñe ña. }\end{array}$ & $\begin{array}{l}\text { Any child who } \\
\text { shoots a } \\
\text { vulture with an } \\
\text { arrow merely } \\
\text { exposes } \\
\text { himself to } \\
\text { public ridicule } \\
\text { because it is } \\
\text { not an edible } \\
\text { bird. }\end{array}$ & $\begin{array}{l}\text { It is used to tell } \\
\text { a child not to } \\
\text { be too heard in } \\
\text { public. }\end{array}$ & $\begin{array}{l}\text { A futile activity } \\
\text { undertaken in } \\
\text { public always } \\
\text { attracts public } \\
\text { opprobrium. }\end{array}$ \\
\hline
\end{tabular}


Sule, Ojonugwa \& Akanya: Igala Proverbs as Correctional ...

A careful look at the proverbs above, shows that the speaker uses them to pre-enact the concept of truth in the mind of the listener and should not claim to be ignorant about certain facts in life. The speaker uses the proverbs in an externalized form to state the universal truth about the subject matter. The speaker tries to maintain some form of distance between the truth, being communicated through the proposition and his words. The proverbs are commonly used by the Igala elders to frown against pretence, complacency, deceit and insincerity. The proverbs are usually used by Igala traditional elders when discussing important issues.

Table 3: Sample of Proverbs Showing Fate and Predestination

\begin{tabular}{|c|c|c|c|}
\hline $\begin{array}{l}\text { Igala Proverb } \\
\text { (IP) }\end{array}$ & $\begin{array}{l}\text { English } \\
\text { Version }\end{array}$ & $\begin{array}{l}\text { Situation of } \\
\text { Use }\end{array}$ & Moral Lesson \\
\hline $\begin{array}{l}\text { Opmẹkpa } \\
\text { ma'kwun, } \\
\text { unawo } \\
\text { d'ejọogba. }\end{array}$ & $\begin{array}{l}\text { A child that } \\
\text { survives } \\
\text { infancy shall } \\
\text { surely grow } \\
\text { into a buoyant } \\
\text { adulthood. }\end{array}$ & $\begin{array}{l}\text { When there is } \\
\text { a close relation } \\
\text { between the } \\
\text { interlocutors }\end{array}$ & $\begin{array}{l}\text { The Igala } \\
\text { people believe } \\
\text { in fate and } \\
\text { predestination } \\
\text { as seen in the } \\
\text { proverb. A } \\
\text { justified end } \\
\text { cannot be } \\
\text { totally } \\
\text { divorced from } \\
\text { a firm } \\
\text { foundation. }\end{array}$ \\
\hline $\begin{array}{l}\text { Ojọ e'jo jọ, } \\
\text { oñwu kpai } \\
\text { a'nọkpa ade. }\end{array}$ & $\begin{array}{l}\text { When it is time } \\
\text { for the snake } \\
\text { to die, it will } \\
\text { meet a man } \\
\text { with a stick }\end{array}$ & $\begin{array}{l}\text { It is used when } \\
\text { the speaker } \\
\text { looks at certain } \\
\text { thing that } \\
\text { cannot be } \\
\text { avoided and } \\
\text { the listener to } \\
\text { know this. }\end{array}$ & $\begin{array}{l}\text { Human lives } \\
\text { most a times } \\
\text { are controlled } \\
\text { by fate and } \\
\text { destination. }\end{array}$ \\
\hline $\begin{array}{llr}\text { Ojọ } & \text { ma } & \text { li } \\
\text { ẹnwu } & \text { ka } & \text { alu } \\
\end{array}$ & $\begin{array}{lr}\text { God } & \text { provides } \\
\text { daily } & \text { since } \\
\end{array}$ & $\begin{array}{l}\text { It is used to } \\
\text { encourage the }\end{array}$ & $\begin{array}{l}\text { The proverbs } \\
\text { harps on the }\end{array}$ \\
\hline
\end{tabular}


Ogirisi: a new journal of African studies vol. 15s 2019

\begin{tabular}{|l|ll|l|l|}
\hline ajẹn ya nwan. & $\begin{array}{l}\text { there is no } \\
\text { time without } \\
\text { day. }\end{array}$ & $\begin{array}{l}\text { youth to wake } \\
\text { up to their } \\
\text { responsibility } \\
\text { and stop being } \\
\text { lazy. }\end{array}$ & $\begin{array}{l}\text { need for hard } \\
\text { sure and be } \\
\text { situation the } \\
\text { borne out of } \\
\text { human error. }\end{array}$ \\
\hline
\end{tabular}

Igala language is blessed with proverbs that open the mind of the Igala people to "what must be, will be". The Igala traditional elders use these proverbs to comment on events which cannot be changed in life. The proverbs further solidify Igala belief system in the unseen power of the gods and cosmic word which can help to shape destinies and future of the younger generation. The Igala proverbs, to a great extent prepare the minds of the youths to be hopeful for a bright future and caution them not to be too in a haste to cut-short their destinies by engaging in sharp practices to earn a living, but be hardworking to make it happen.

Table 4: Samples of Proverbs that show Respect for Elders and the Constituted Authorities

\begin{tabular}{|l|l|l|l|}
\hline $\begin{array}{l}\text { Igala Proverb } \\
\text { (IP) }\end{array}$ & $\begin{array}{l}\text { English } \\
\text { Version }\end{array}$ & $\begin{array}{l}\text { Situation of } \\
\text { Use }\end{array}$ & Moral Lesson \\
\hline $\begin{array}{l}\text { I'mọtọ f'ọñ } \\
\text { gwẹ kifẹ iaje } \\
\text { nw kpai onu. }\end{array}$ & $\begin{array}{l}\text { If a child } \\
\text { watches his } \\
\text { hand clean, he } \\
\text { eats with the } \\
\text { kings. }\end{array}$ & $\begin{array}{l}\text { It used when } \\
\text { an elder wants } \\
\text { to advice the } \\
\text { child on what } \\
\text { will take the } \\
\text { child to the } \\
\text { height hou mo } \\
\text { wants to be. }\end{array}$ & $\begin{array}{l}\text { ff } \\
\text { respect to the } \\
\text { elders. }\end{array}$ \\
\hline $\begin{array}{l}\text { Oji k'one ańo, } \\
\text { ia kpa b'uta } \\
\text { tọn }\end{array}$ & $\begin{array}{l}\text { No one kills a } \\
\text { toad and throw } \\
\text { it into stream } \\
\text { that he drinks. }\end{array}$ & $\begin{array}{l}\text { It is used when } \\
\text { an elder tells a } \\
\text { child not to } \\
\text { destroy what } \\
\text { will serve him }\end{array}$ & $\begin{array}{l}\text { Do not destroy } \\
\text { the system that } \\
\text { will serve you } \\
\text { tomorrow. }\end{array}$ \\
\hline
\end{tabular}


Sule, Ojonugwa \& Akanya: Igala Proverbs as Correctional ...

\begin{tabular}{|l|l|l|l|}
\hline & & tomorrow & \\
\hline $\begin{array}{l}\text { Uma ma du bi } \\
\text { ola }\end{array}$ & $\begin{array}{l}\text { Had I known } \\
\text { always comes } \\
\text { last }\end{array}$ & $\begin{array}{l}\text { When there is } \\
\text { need for a } \\
\text { child to learn }\end{array}$ & $\begin{array}{l}\text { Do not be } \\
\text { foully with the } \\
\text { elders. }\end{array}$ \\
\hline
\end{tabular}

Igala proverbs are indeed correctional tools in the hands of the elders as evident in the data provided above. From the above it become clear that proverbs are an integral part of Igala language and Igala people and it forms an essential component of the sum of the achievement of the society or the people. The proverbs are composed of ingredients that are embedded in the culture of Igala people. It is usually the revelation of the philosophy of the people; and the moral values that the society holds on to it is the system that educates people and gives them a guide for their future life. It is constantly serves as correctional tools in the hand of the Igala traditional elders. The data above affirm the fact that no one is born today, becomes a king today; for a child to rise to an enviable height must learn to respect elders, follow elders and obey certain rules and regulations guide the operation of the community where he comes from.

\section{Discussion}

From the data above, it is clear that proverbs are part of Igala people and they use it mostly as correctional tools to correct their children, shape their tomorrow and expose them to the dos and don'ts of the society. Unlike in some cultures where flogging and public disgrace are part of child training, Igala traditional elders reserve special way in the correction of their children. In the context of this study, Igala proverbs are assertive, corrective and directional, this is because, the proverbs are expression of folk, which contains above all wisdom, expression of universal truth about life, evergreen and timeless and highly philosophical, and it also fits into universal issues of all human discourse and a product of the society rather than that of an individual, in which the true value cannot be contested for, and usually serves as speech for all the elders in all the seasons. 
There are special respects that are meant only for the elders in the society that are best expressed in the proverbs. The child must have to learn respect for and love of life, and this has to do with respect for the elderly who are not taken into any old people's homes when age tells on them, but are catered for by relatives and friends. Children are taken as visible signs of hope for tomorrow, therefore some social vices that came along with western education such as abortion, suicide, incest, violence, murder, cultism, indecency and so forth are better corrected through the use of appropriate proverbs rather that the use of force.

Igala proverbs are capable of institutionalizing moral values such as respect for elders, chastity of women folk, dignity of labour, communalism, filial piety, integrity, truthfulness, belief in God, courage and hospitality.

\section{Conclusion}

In conclusion, the Igala proverbs are concise and powerful and they are used by Igala people to achieve true and full development of their younger generation for a better and a peaceful society by means of cultivating the lives of the Igala people particularly the Igala youth in line with their naturally endowed culture. By so doing, the Igala traditional elders can be doubly assured of contributing something quite original to the development of the entire humanity.

\section{*Sunday Emah Sule, Ph.D}

Department of Arts Education

Kogi State University, Anyigba

Email:emahsule1@gmail.com

\section{*Sunday Joseph Ojonugwa}

Department of Arts Education

Kogi State University, Anyigba

Email: ugwa4christ70@yahoo.com

\section{*Joseph Akanya}

Department of Arts Education

Kogi State University, Anyigba

Email: akanya_joseph@gmail.com 


\section{References}

Egbunu, Fidelis Eleojo. Education and Re-Orientation of Igala Cultural Values. Igala Education Summit, KSU, Anyigba. 2011.

. Chieftaincy Titles Among Igala: Problems and Prospects for Christians. Enugu: Snaap Press. 2001.

. Religious, Politics and Patriotism in Africa:

A Christian Perspective. Nsukka: Afro-Orbis. 2009.

Egwemi, J.O. Ibaji: My District, My Constituency and My Local Government Area. Markudi: Satos. 1983.

Idegu, E.I. The Legendary Inikpi. Ibadan: University Press. 2004.

Edimeh, F. The Legacies of Attah Ayegba Omi-Idoko: A Concise History of Igala and Ankpa Land. CUACA. 2006.

Achor, E. Addressing the Problem of Examination Malpractice in Kogi East Senatorial District for Improved Enrolment in Science and Technology Related Courses. A Paper at Igala Education Summits, KSU, Anyigba. 2009.

Sperber, D. and Wilson, D. Relevance: Communication and Cognition. Oxford: Blackwell Publishers. 1986. 